\title{
$\beta$-asarone inhibits gastric cancer cell proliferation
}

\author{
JIAN WU*, XING-XING ZHANG ${ }^{*}$, QING-MIN SUN, MIN CHEN, SHENG-LIN LIU, \\ XIANG ZHANG, JIN-YONG ZHOU and XI ZOU
}

\begin{abstract}
Department of Oncology, The Affiliated Hospital of Nanjing University of Chinese Medicine, Jiangsu Province Hospital of Traditional Chinese Medicine, Nanjing, Jiangsu 210029, P.R. China
\end{abstract}

Received March 21, 2015; Accepted August 26, 2015

DOI: $10.3892 /$ or.2015.4316

\begin{abstract}
Chinese herb Rhizoma Acori Tatarinowii. It exhibits a wide range of biological activities in many human organs. However, few studies have investigated the effect of $\beta$-asarone on gastric cancer. The present study investigated the effect of $\beta$-asarone on the proliferation and apoptosis of three types of differentiated human gastric cancer cell lines (SGC-7901, BGC-823 and MKN-28) in vitro as well as the related molecular mechanisms. Methyl thiazolyl tetrazolium assay, Annexin V/ PI double staining, immunofluorescence test and transmission electron microscopy all confirmed that $\beta$-asarone had an obvious dose-dependent inhibitive effect on the proliferation of human gastric cancer cells and induced apoptosis of the cell lines. Transwell invasion, wound-healing and matrix-cell adhesion experiments confirmed that $\beta$-asarone inhibited the invasion, migration and adhesion of human gastric cancer BGC-823 cells. Quantitative real-time PCR and western blotting found that $\beta$-asarone significantly activated caspase-3, caspase-8, caspase-9, Bax, Bak and suppressed $\mathrm{Bcl}-2, \mathrm{Bcl}-\mathrm{xL}$ and survivin activity. Moreover, $\beta$-asarone increased the expression of RECK, E-cadherin and decreased the expression of MMP-2, MMP-9, MMP-14 and N-cadherin. The present study demonstrated that $\beta$-asarone effectively inhibits the proliferation of human gastric cancer cells, induces their apoptosis and decreased the invasive, migratory and adhesive abilities.
\end{abstract}

\section{Introduction}

Gastric cancer is a common gastrointestinal tumor. Its mortality rate ranks second among men and fourth among women $(1,2)$. At present, surgery is the primary therapy for this

Correspondence to: Dr Xi Zou, Department of Oncology, The Affiliated Hospital of Nanjing University of Chinese Medicine, Jiangsu Province Hospital of Traditional Chinese Medicine, 155 Hanzhong Road, Nanjing, Jiangsu 210029, P.R. China

E-mail: zxvery@126.com

*Contributed equally

Key words: $\beta$-asarone, gastric cancer, proliferation, mechanism disease and may achieve satisfactory results when combined with chemotherapy. However, for advanced gastric cancer, surgical therapy is not satisfactory.

Natural products are important resources for anticancer chemical agents. Thus, a significant strategy for developing anticancer drugs is to identify effective and active ingredients from natural products.

$\beta$-asarone $\left(\mathrm{C}_{12} \mathrm{H}_{16} \mathrm{O}_{3}, \mathrm{MW} 208.5\right)$ is the main volatile oil of Chinese herb Rhizoma Acori Tatarinowii. It exhibits therapeutic effects on many organs of the human body displaying many biological activities. Numerous studies have illustrated that $\beta$-asarone regulates the nervous system (3), kills parasites and bacteria (4) and prevents cholesterol synthesis (5). Previous laboratory research found that $\beta$-asarone significantly inhibited the growth of colon cancer (6). However, there is no study concerning its effects on gastric cancer cells and the related mechanism. Accordingly, the present study aimed to investigate the impact of $\beta$-asarone on human gastric cancer cells and to explore the possible mechanism.

\section{Materials and methods}

Cell culture. Three types of cell lines, low-differentiated human gastric cancer cell line BGC-823, moderately differentiated human gastric cancer cell line SGC-7901 and highly differentiated human gastric cancer cell line MKN-28, were obtained from the Type Culture Collection, Chinese Academy of Sciences (Shanghai, China), and were routinely cultured in RPMI-1640 medium containing $10 \%$ bovine serum at $37^{\circ} \mathrm{C}$ with $5 \% \mathrm{CO}_{2}$.

Drugs and reagents. $\beta$-asarone, methyl thiazolyl tetrazolium and $\beta$-actin were purchased from Sigma-Aldrich Co. LLC. RPMI-1640 medium was purchased from HyClone, USA, bovine serum was purchased from Hangzhou Sijiqing Biological Engineering Materials Co., Ltd. and $0.25 \%$ trypsin was purchased from Biosharp Biological Technology Co., Ltd. Annexin V/PI was purchased from KeyGen Biotech Co. Ltd. and TRIzol and SYBR-Green were obtained from Life Science and Technology Co. Real-time PCR reverse transcription kit was purchased from Takara Co. Ltd. and antibodies against caspase-3, -8, and -9, Bax, Bak, Bcl-xL, MMP-2, MMP-9, MMP-14, RECK, E-cadherin, N-cadherin and $\beta$-actin were purchased from Cell Signaling Co., USA. Bcl-2 was purchased from GeneTex, Inc. and NR2B and GluR2 as the secondary 
antibodies were purchased from ZSGB-Bio Co. All of the reagents were analytically pure.

MTT assay. The growth inhibitory effect of $\beta$-asarone was measured by methyl thiazolyl tetrazolium (MTT) assay. Human gastric cancer cells in a logarithm growth phase were inoculated into a 96 -well plate at a density of $6 \times 10^{3} /$ well. After the cells adhered for $24 \mathrm{~h}$, the medium in the plate was discarded, and $\beta$-asarone was mixed with RPMI-1640 medium. The mixed solution with $\beta$-asarone at a concentration of $0,0.48$, $0.24,0.12,0.06$ or $0.03 \mathrm{mM}$ were added into the 96 -well plate and the cells were further incubated at $37^{\circ} \mathrm{C}$ with $5 \% \mathrm{CO}_{2}$ for $24 \mathrm{~h}$. Afterwards, $5 \mu \mathrm{l}$ MTT $(5 \mathrm{mg} / \mathrm{ml})$ was added into each well. Four hours later, the dark blue formazan precipitates were dissolved, and $150 \mu \mathrm{l}$ dimethylsulfoxide (DMSO) was added into each well. The absorbance value was detected by an enzyme-linked immunosorbent assay (ELISA) at a wavelength of $490 \mathrm{~nm}$ to calculate the inhibitory rate of $\beta$-asarone for cancer growth. The assay was repeated three times.

Flow cytometric analysis. The gastric cancer cells were treated with 0.12 and $0.24 \mathrm{mM} \beta$-asarone and 5-fluorouracil (5-FU) $(50 \mu \mathrm{g} / \mathrm{ml})$ under the same conditions as the MTT assay. After treatment with $\beta$-asarone for $24 \mathrm{~h}$, the cells were collected, washed with cold phosphate-buffered saline (PBS), and resuspended in binding buffer at a density of $8 \times 10^{5} / \mathrm{ml}$. Subsequently, the cells were stained with $5 \mu \mathrm{l}$ Annexin $\mathrm{V}$ and $5 \mu \mathrm{l}$ PI for $15 \mathrm{~min}$ in the absence of light. Apoptosis of the cells was detected by flow cytometry within $1 \mathrm{~h}$.

Fluorescent immunocytochemistry test. Three types of gastric cancer cells were plated into a 6-well plate at a density of $3 \times 10^{5} /$ well. After adhering for $24 \mathrm{~h}$, the cells were treated with $\beta$-asarone $(0.12$ and $0.24 \mathrm{mM})$ and 5 -FU $(50 \mu \mathrm{g} / \mathrm{ml})$ for $24 \mathrm{~h}$ and washed with PBS twice. To detect the nuclei, cells were incubated with Hoechst for 10 min, stained by Hoechst 33342 solution for $20 \mathrm{~min}$ and washed with PBS three times. Afterwards, the nuclei were photographed using a fluorescence microscope.

Electron microscopic analysis. After treatment with $\beta$-asarone $(0.24 \mathrm{mM})$ for $24 \mathrm{~h}$, the cells were fixed in $2.5 \%$ glutaraldehyde, $4 \%$ paraformaldehyde, post-fixed with $1 \%$ osmium tetroxide, dehydrated and in-layed by epoxy resin. The cells were cut into 80 -nm sections which were stained with lead uranyl acetate and detected by a JEM-1010 electron microscope (JEOL, Japan) at $80 \mathrm{kV}$.

Transwell assay. Low-differentiated human gastric cancer BGC-823 cells with stronger invasive potential were inoculated in a culture dish for $24 \mathrm{~h}$. Cells $\left(6 \times 10^{5}\right)$ in media supplemented with $1 \%$ FBS were plated onto the upper chambers coated with Matrigel, and $600 \mu 1$ media supplemented with $10 \%$ FBS was added into the lower chambers. After treatment with $\beta$-asarone $(0.12$ and $0.24 \mathrm{mM})$ or $50 \mu \mathrm{g} / \mathrm{ml} 5-\mathrm{FU}$ for $24 \mathrm{~h}$, the cells were fixed and stained with $0.1 \%$ crystal violet. The non-migrated cells were wiped off and the migrated cells were photographed.

Wound-healing assay. BGC-823 cells were cultured into a 24 -well plate $\left(1 \times 10^{6} /\right.$ well). Once $100 \%$ confluence was
Table I. Sequences of the primers used in the RT-PCR amplifications.

\begin{tabular}{|c|c|c|}
\hline Gene primes & Sequences $\left(5^{\prime}-3^{\prime}\right)$ & $\begin{array}{l}\text { ength of PCR } \\
\text { product (bp) }\end{array}$ \\
\hline Bax & $\begin{array}{l}\text { F TTTGCTTCAGGGTTTCATCC } \\
\text { R GCCACTCGGAAAAAGACCTC }\end{array}$ & 213 \\
\hline Bak & $\begin{array}{l}\text { F ACGCTATGACTCAGAGTTCC } \\
\text { R CTTCGTACCACAAACTGGCC }\end{array}$ & 360 \\
\hline Bcl-xL & $\begin{array}{l}\text { F ATGAACTCTTCCGGGATGG } \\
\text { R TGGATCCAAGGCTCTAGGTG }\end{array}$ & 166 \\
\hline Bcl-2 & $\begin{array}{l}\text { F TCGCCCTGTGGATGACTGAG } \\
\text { R CAGAGTCTTCAGAGACAGCCAGGA }\end{array}$ & 143 \\
\hline Survivin & $\begin{array}{l}\text { F TTCTCAAGGACCACCGCATC } \\
\text { R GCCAAGTCTGGCTCGTTCTC }\end{array}$ & 127 \\
\hline $\mathrm{N}$-cadherin & $\begin{array}{l}\text { F GTGCCATTAGCCAAGGGAATTCAGC } \\
\text { R GCGTTCCTGTTCCACTCATAGGAGG }\end{array}$ & $\begin{array}{l}\mathrm{iC} \\
\mathrm{G}\end{array}$ \\
\hline E-cadherin & $\begin{array}{l}\text { F GGTGCTCTTCCAGGAACCTC } \\
\text { R CAGCAACGTGTTTCTGCATTTC }\end{array}$ & 196 \\
\hline RECK & $\begin{array}{l}\text { F ATCTGTTCACCCTGGAGT } \\
\text { R TGTTGAAGTGTTTGCTTT }\end{array}$ & 96 \\
\hline MMP-2 & $\begin{array}{l}\text { F CTCCCGGAAAAGATTGATG } \\
\text { R GGTGCTGGCTGAGTAGAT }\end{array}$ & 96 \\
\hline MMP-9 & $\begin{array}{l}\text { F TCTATGGTCCTCGCCCTGAA } \\
\text { R CATCGTCCACCGGACTCAAA }\end{array}$ & 219 \\
\hline MMP-14 & $\begin{array}{l}\text { F ATCTGCCTCTGCCTCACCTA } \\
\text { R AAGCCCCATCCAAGGCTAAC }\end{array}$ & 126 \\
\hline$\beta$-actin & $\begin{array}{l}\text { F GGCCAACCGCGAGAAGAT } \\
\text { R CGTCACCGGAGTCCATCA }\end{array}$ & 134 \\
\hline
\end{tabular}

observed, the cell monolayer was scratched with a pipette tip and washed with PBS twice. The cells were treated with $\beta$-asarone $(0.12$ and $0.24 \mathrm{mM})$ or $50 \mu \mathrm{g} / \mathrm{ml} 5$-FU for $24 \mathrm{~h}$. The width of the scratches was photographed for analysis.

Cell matrix adhesion assay. BGC-823 cells were inoculated in a culture dish until they adhered to the plate surface. $\beta$-asarone $(0.12$ and $0.24 \mathrm{mM})$ and $5-\mathrm{FU}(50 \mu \mathrm{g} / \mathrm{ml})$ were added and maintained for $24 \mathrm{~h}$. The cells were digested and centrifuged. The precipitated cell suspension was resuspended with culture medium containing the original medicine. Approximately $1 \times 10^{5}$ live cells were seeded into each well of a 96-well plate coated with fibronectin. The original medicated medium was discarded every $30 \mathrm{~min}$, and the cells were cultured with RPMI-1640 medium. Afterwards (120 min), $5 \mu \mathrm{l}$ MTT (5 mg/ $\mathrm{ml}$ ) was added into each well. After $4 \mathrm{~h}$ of cultivation, ELISA was used to read the absorption values at a 490-nm wavelength.

Assessment of $m R N A$ expression. Having been incubated with $\beta$-asarone for $24 \mathrm{~h}$, the human gastric cancer cell lines were assessed by RT-PCR to determine the effect of $\beta$-asarone on the mRNA expression of apoptosis- and metastasis-associated genes. Total RNA from the cells was isolated using TRIzol reagent. Subsequently, $1 \mu \mathrm{g}$ of the extracted total RNA was reverse-transcribed into first-strand complementary DNA 


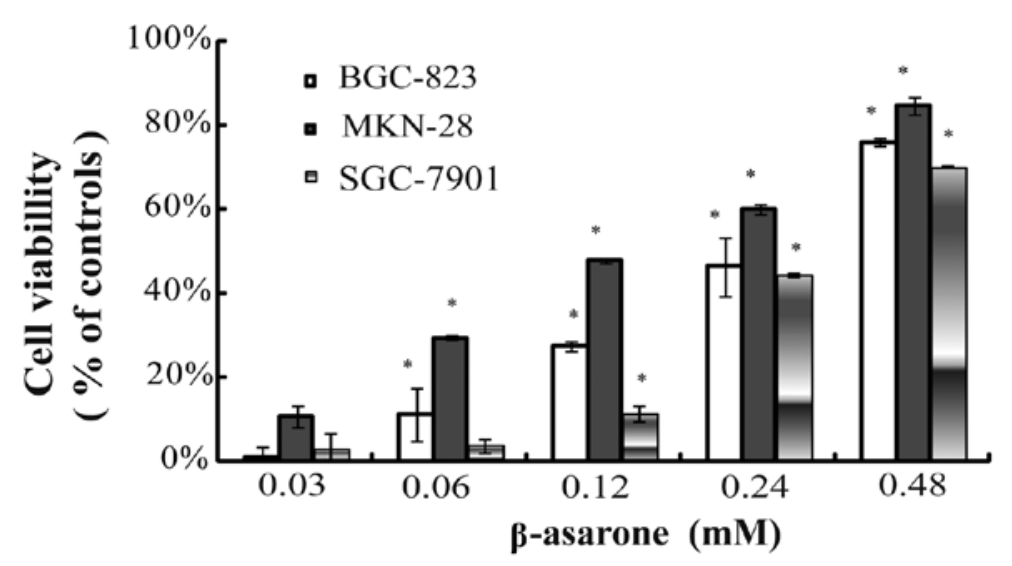

Figure 1. Anti-proliferative effect of $\beta$-asarone on human gastric cancer cells. MTT assay showed that the viability of three human gastric cancer cell lines were reduced after treament with different concentrations $(0.03-0.48 \mathrm{mM})$ of $\beta$-asarone for $24 \mathrm{~h}$ in a dose-dependent manner $(\mathrm{P}<0.05)$.

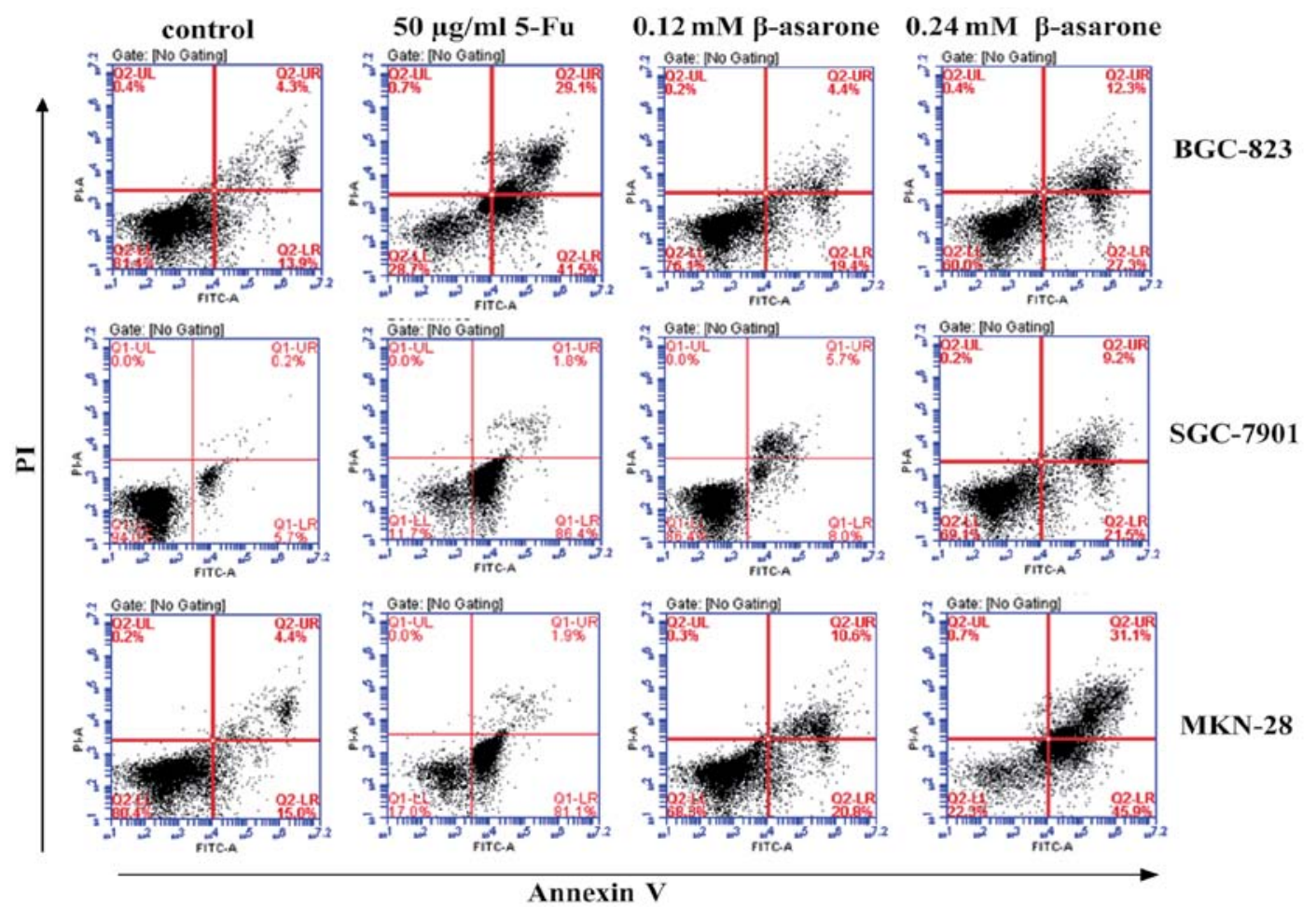

Figure 2. Flow cytometric analysis of human gastric cancer cell apoptosis following treatment with $\beta$-asarone for $24 \mathrm{~h}$. The dual parameter dot plots combining Annexin V-FITC and PI fluorescence showed the viable cell population in the lower left quadrant (Annexin V-PI'), the early stage apoptotic cells in the lower right quadrant (Annexin $\left.\mathrm{V}^{+} \mathrm{PI}\right)$ and the late stage apoptotic or dead cells in the upper right quadrant (Annexin $\left.\mathrm{V}^{+} \mathrm{PI}^{+}\right)$.

(cDNA) using the High-Capacity cDNA Reverse Transcription kit according to the manufacturer's instructions. They were then performed on 7500 Fast RT-PCR system, using DNA-binding dye SYBR-Green. The $\Delta \Delta \mathrm{Ct}$ method was used for qPCR. The sequences of the primers used to specifically amplify the genes of interest are shown in Table I.

Western blot analysis. After $24 \mathrm{~h}$ of incubation with $\beta$-asarone, the gastric cancer cell lines were assessed by western blotting to detect the activity of the apoptosis- and metastasis-associated proteins. The cell lysates were separated by $12 \%$ SDS-PAGE, and transferred to a polyvinylidene fluoride membrane, blocked with 5\% skimmed milk for $1 \mathrm{~h}$, and incubated with the primary antibodies (1:1,000 dilution) overnight at $4^{\circ} \mathrm{C}$. Having been incubated with horseradish peroxidase-conjugated secondary antibody, ECL liquid was obtained for lighting and banding analysis.

Statistical analysis. Data are presented as the mean values \pm SD. Differences between the mean values for individual groups were assessed using one-way ANOVA followed by Duncan's multiple range tests. Differences were considered significant at $\mathrm{P}<0.05$. SPSS 13.0 was applied for statistical analysis.

\section{Results}

$\beta$-asarone inhibits the proliferation of gastric cancer cells. Human gastric cancer cells were treated with $0,0.48,0.24$, 


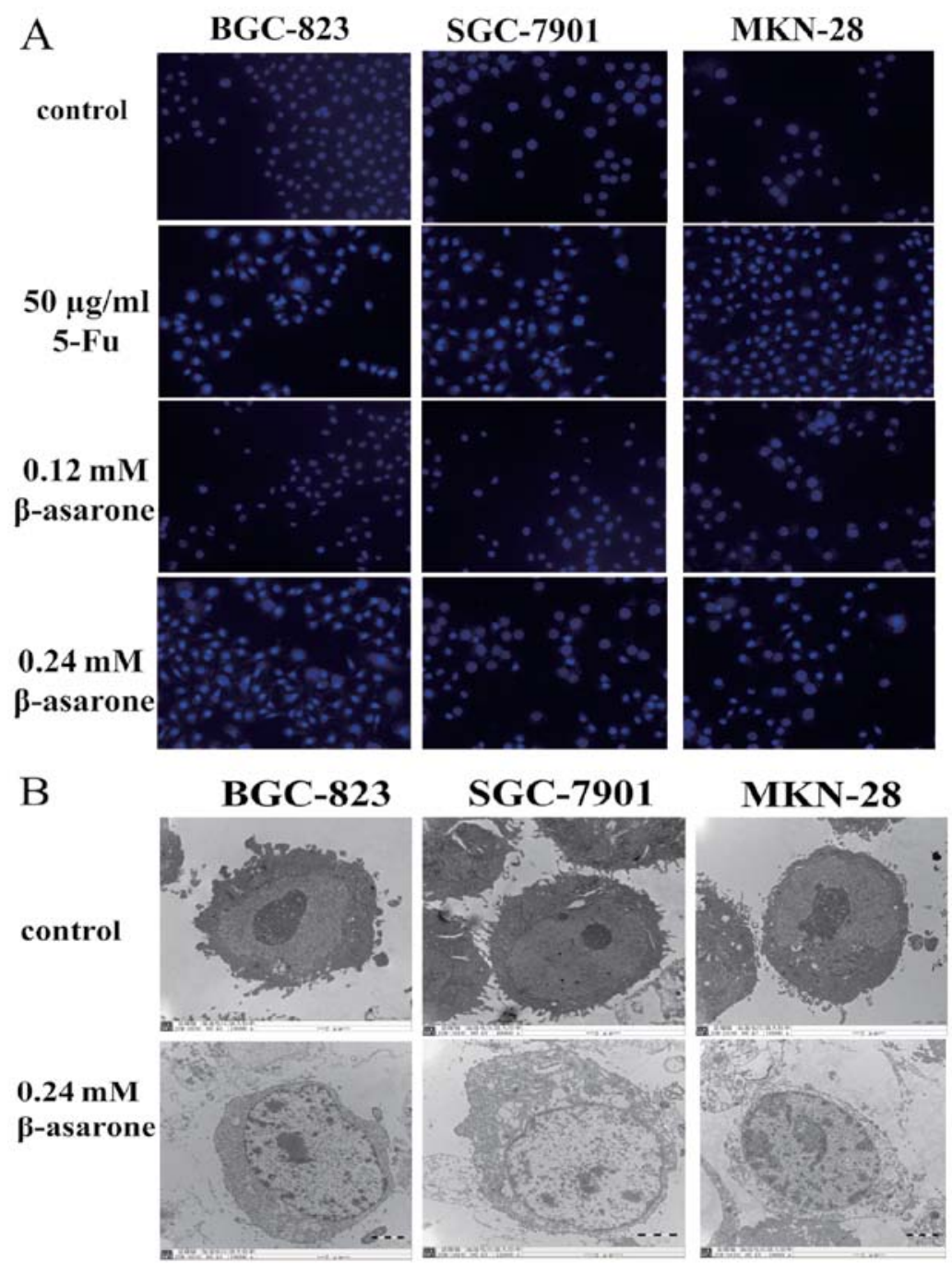

Figure 3. (A) Cell morphology was observed under a fluorescence microscope following staining with Hoechst 33342. Arrows indicate apoptotic cells with fragmented nuclei and nuclear shrinkage. Magnification, x200. (B) Transmission electron microscopic observation (magnification, x8,000). Compared with the control cells, the treated cells underwent nuclear shrinking, cytoplasmic vacuolization and expansion of endoplasmic reticulum and accumulation of condensed chromatin, indicative of apoptosis. Scale bar, $2 \mu \mathrm{m}$.

$0.12,0.06$ and $0.03 \mathrm{mM} \beta$-asarone, respectively, for up to $24 \mathrm{~h}$. $\beta$-asarone exhibited an inhibitory effect on the proliferation of the cells in a dose-dependent manner. The inhibitory rate of $\beta$-asarone at the concentration of $0.48 \mathrm{mM}$ for BGC-823, MKN-28 and SGC-7901 cells within $24 \mathrm{~h}$ was $75.79 \pm 3.12$, $84.42 \pm 0.38$ and $69.85 \pm 1.91 \%$, respectively (Fig. 1).

$\beta$-asarone induces the apoptosis of gastric cancer cells. Flow cytometric analysis detected the early apoptosis of the human gastric cancer cells $24 \mathrm{~h}$ after $\beta$-asarone treatment. Following treatment at concentrations of 0.12 and $0.24 \mathrm{mM} \beta$-asarone, the early apoptosis rate of the BGC-823, SGC-7901 and MKN-28 cells rose from 19.4 to $27.3 \%, 8$ to $21.5 \%$ and 20.8 to $45.9 \%$, respectively. Meanwhile, the apoptosis rate of the positive control group was 41.5\% (BGC-823), 86.4\% (SGC-7901) and $81.1 \%$ (MKN-28) (Fig. 2).

$\beta$-asarone alters the structure of gastric cancer cells. In order to observe the structural changes in the gastric cancer cells following treatment with $\beta$-asarone, both fluorescence microscopy and transmission electron microscopy were utilized.
The cells stained with Hochest 33342 were observed under a fluorescence microscope (magnification, $x 200$ ). The nuclei of the cells treated by $\beta$-asarone were fragmented and shrunken which indicated apoptosis (Fig. 3A).

Transmission electron microscopy (magnification, $\mathrm{x} 8000$ ) found nuclear atrophy, cytoplasmic vacuolization, endoplasmic reticulum expansion and chromatin edge gathering in the cells, which were also indicative of cell apoptosis (Fig. 3B). Thus, $\beta$-asarone significantly induced apoptosis in the gastric cancer cells.

$\beta$-asarone prohibits the migration and invasion of $B G C-823$ cells. In order to observe the effect of $\beta$-asarone on the migration and invasion of gastric cancer cells, low-differentiated BGC-823 cells were chosen as the target. Both Transwell (Fig. 4A and B) and wound-healing assays (Fig. $4 \mathrm{C}$ ) revealed that $\beta$-asarone inhibited the migration of BGC-823 cells in a concentration-dependent manner. $\beta$-asarone efficiently suppressed the cell invasion in a dose-dependent manner as determined by the Matrigel-coated Transwell assay. Furthermore, compared with the control 


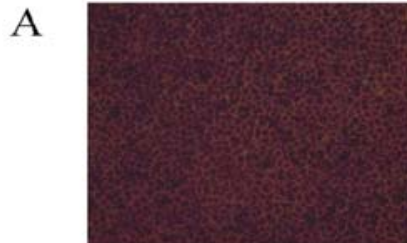

control

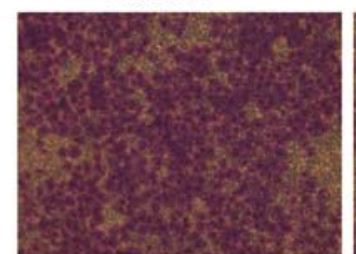

C

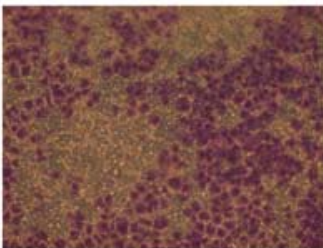

$50 \mu \mathrm{g} / \mathrm{ml} \mathrm{5-Fu}$

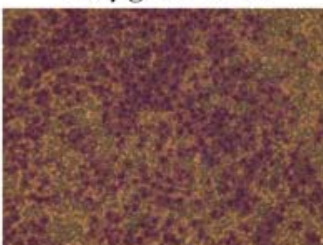

$0.24 \mathrm{mM} \beta$-asarone

$\mathrm{B}$

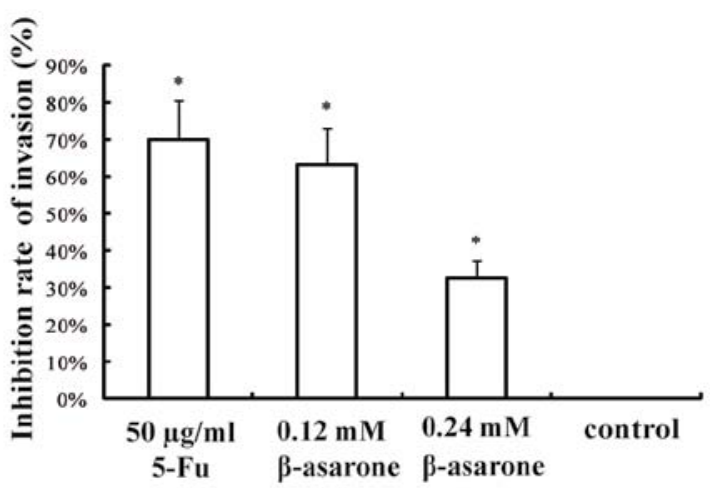

D

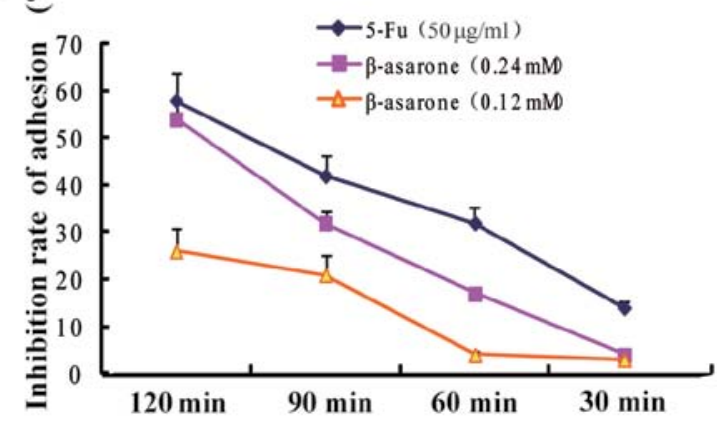

Figure 4. (A) The Transwell assay detected the effects of $\beta$-asarone on the invasiveness of BGC-823 cells. Light microscopic images of the cells treated with different concentrations of $\beta$-asarone (magnification, $\mathrm{x} 400$ ) were captured. (B) The number of BGC-823 cells that migrated across the 8- $\mu \mathrm{m}$ diameter pores to the lower chamber. (C) The wound-healing assay assay detected the effect of $\beta$-asarone on the migration of BGC-823 cells, which were photographed $24 \mathrm{~h}$ after wounding (magnification, x100). White lines indicate wound edges. Cells between the two white lines were the cells which migrated into the wound area. (D) A cell matrix adhesion assay was used to detect the adhesive ability of the BGC-823 cells following treatment with $\beta$-asarone. Each point on the curve is the inhibition rate of cell adhesion of different concentrations at different periods (30, 60, 90 and $120 \mathrm{~min})$.
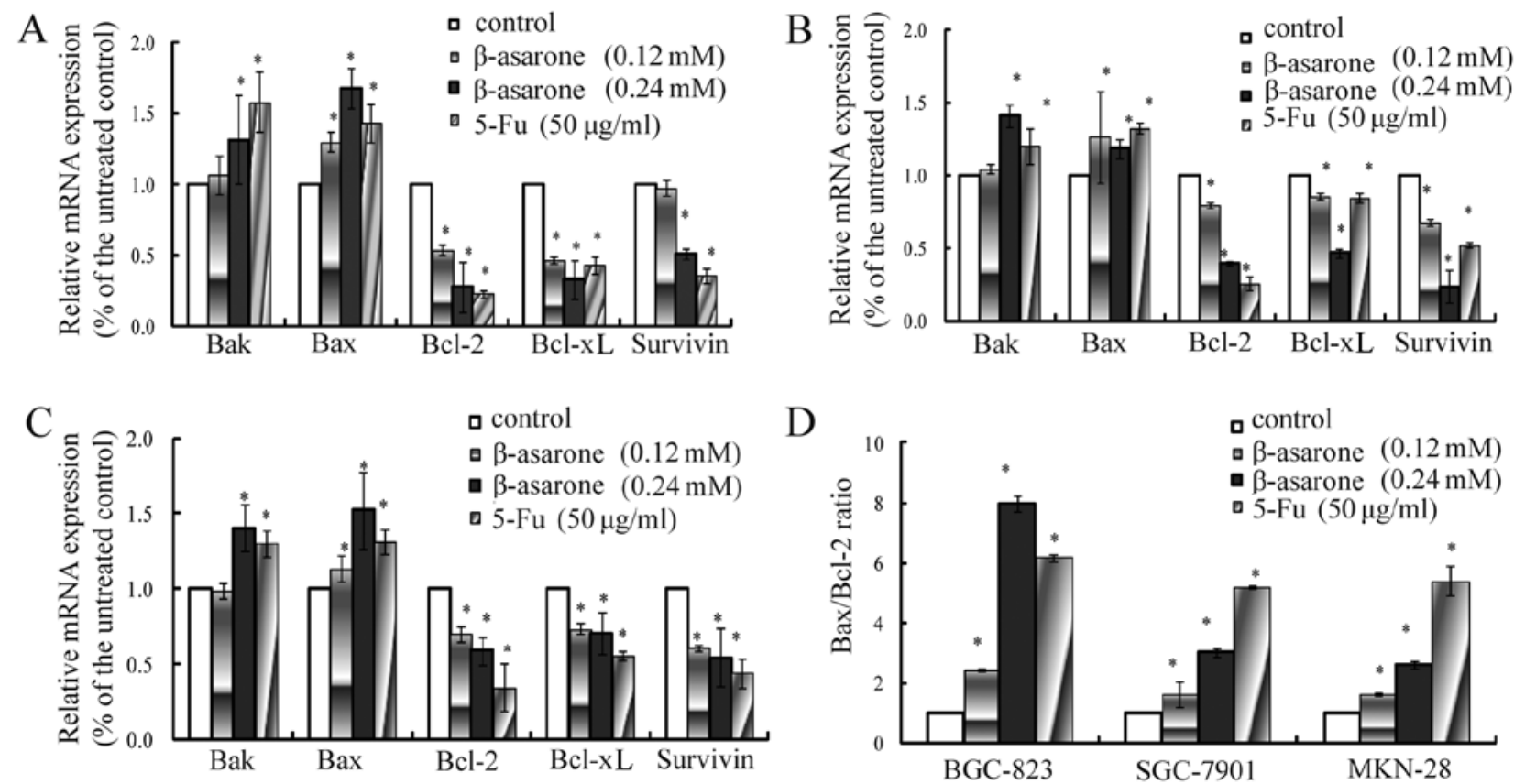

Figure 5. After (A) BGC-823, (B) SGC-7901 and (C) MKN-28 cells were treated with $\beta$-asarone (0.12 and $0.24 \mathrm{mM})$ for $24 \mathrm{~h}$, the mRNA levels of apoptosis-related genes (Bax, Bcl-2, Bcl-xL, Bak and survivin) were determined by RT-PCR. $\beta$-actin was taken as a loading control and 5 -FU (50 $\mu \mathrm{g} / \mathrm{ml})$ as a positive control. (D) The Bax/Bcl-2 ratios of mRNA levels in gastric cancer cells treated with $\beta$-asarone $(0.12$ and $0.24 \mathrm{mM}) .{ }^{*} \mathrm{P}<0.05$.

group, the area of the treated cells in the 6-well plate which migrated into the whole wound area was markedly decreased, suggesting that $\beta$-asarone also suppressed the migration of BGC-823 cells in a dose-dependent manner. 


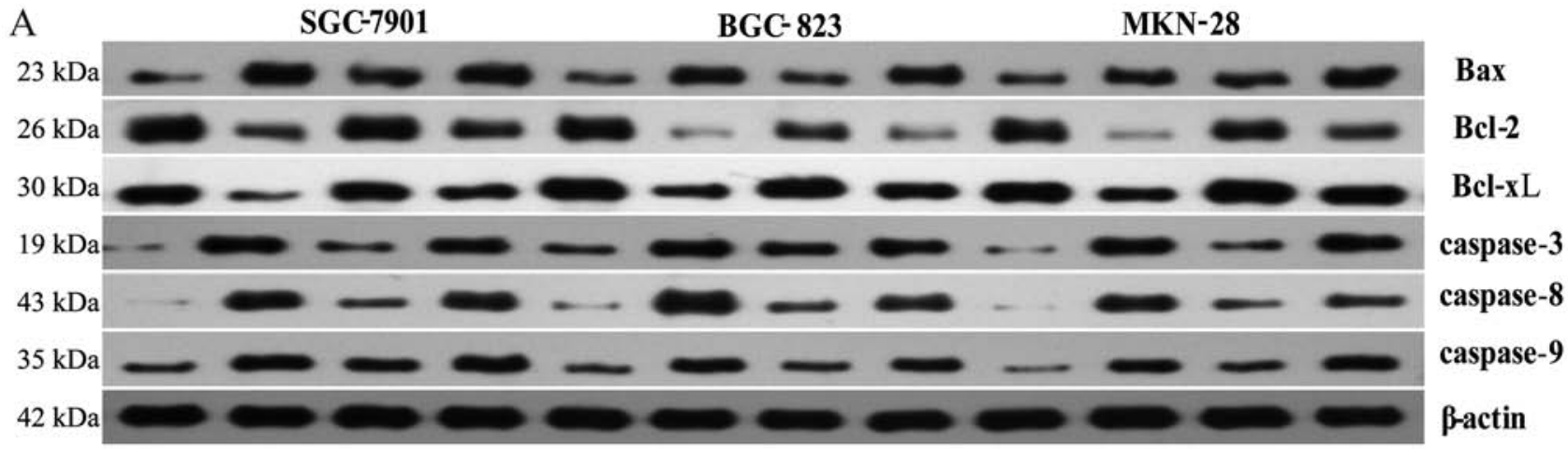

control $0.12 \mathrm{mM} 0.24 \mathrm{mM} 50 \mu \mathrm{g} / \mathrm{ml}$ control $0.12 \mathrm{mM} 0.24 \mathrm{mM} 50 \mu \mathrm{g} / \mathrm{ml}$ control $0.12 \mathrm{mM} 0.24 \mathrm{mM} 50 \mu \mathrm{g} / \mathrm{ml}$

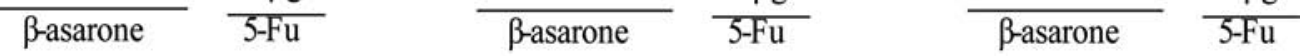

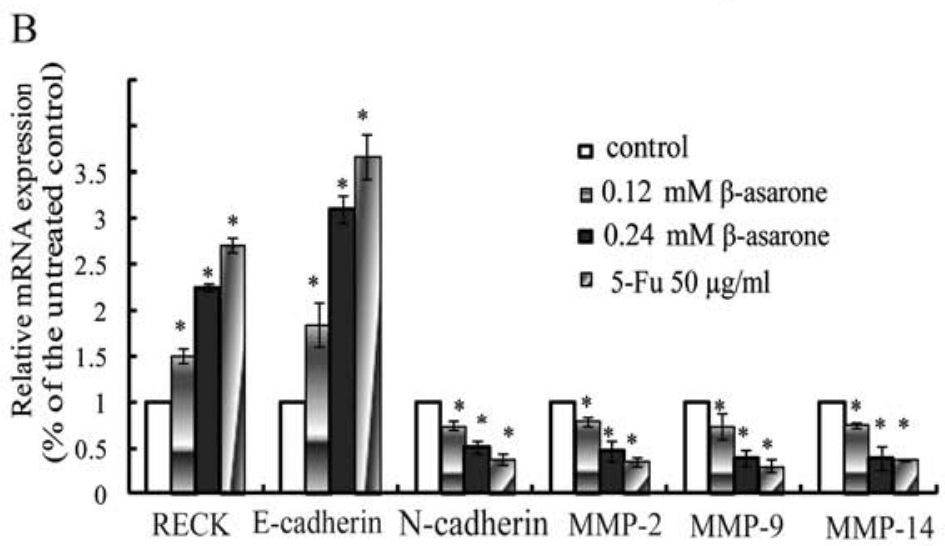

C BGC-823

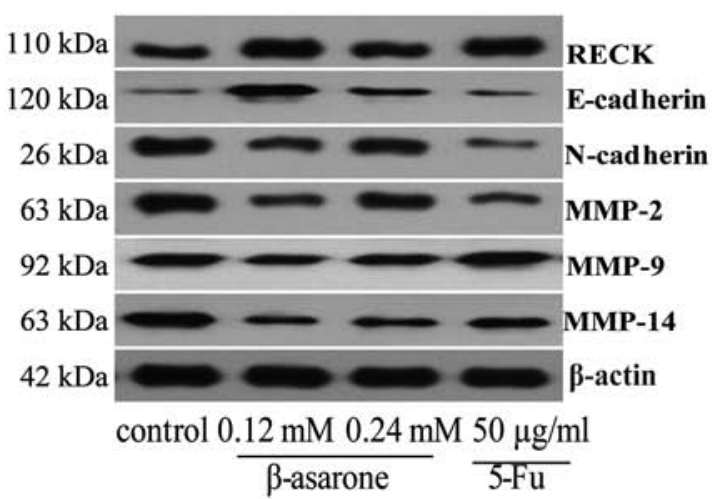

Figure 6. (A) After BGC-823, SGC-7901 and MKN-28 cells were treated with $\beta$-asarone (0.12 and $0.24 \mathrm{mM})$ for $24 \mathrm{~h}$, the levels of apoptosis-related proteins (Bax, Bcl-2, Bcl-xL, caspase-3, -8 and -9) were determined by western blotting. $\beta$-actin was taken as a loading control and 5-FU (50 $\mu \mathrm{g} / \mathrm{ml})$ as a positive control. (B) RT-PCR analysis of invasion-related molecules. After BGC-823 cells were treated with $\beta$-asarone (0.12 and $0.24 \mathrm{mM})$ for $24 \mathrm{~h}$, the mRNA levels of invasion and EMT-related genes (RECK, E-cadherin, N-cadherin, MMP-2, MMP-9 and MMP-14) were detected. $\beta$-actin was used as an internal control. ${ }^{*} \mathrm{P}<0.05$. (C) After BGC-823 cells were treated with $\beta$-asarone $(0.12$ and $0.24 \mathrm{mM})$ for $24 \mathrm{~h}$, the expression changes in the proteins closely associated with invasion and adhesion (RECK, E-cadherin, N-cadherin, MMP-2, MMP-9 and MMP-14) were detected. $\beta$-actin was used as an internal control and 5-FU $(50 \mu \mathrm{g} / \mathrm{ml})$ as a positive control.

$\beta$-asarone inhibits the adhesive ability of the BGC-823 cells. Cell matrix adhesion assay was performed to evaluate the effect of $\beta$-asarone on gastric cancer cell adhesion. We found that the adhesion rate at each time point was lower than that of the control group. Further data demonstrated that the inhibitory rate of adhesion increased as the concentration of $\beta$-asarone and the treatment time increased (Fig. 4D). Therefore, $\beta$-asarone significantly prevented gastric cancer cells from adhering to fibronectin, and the inhibition rate was exhibited in a dose- and time-dependent manner.

Changes in the mRNA and protein expression of apoptosisrelated genes. In order to further study the mechanism of $\beta$-asarone action on the apoptosis of gastric cancer cells, RT-PCR and western blotting were applied to analyze changes in the mRNA and protein levels. RT-PCR showed that after $24 \mathrm{~h}$ of incubation of BGC-823 (Fig. 5A), SGC-7901 (Fig. 5B), MNK-28 (Fig. 5C) cells with $\beta$-asarone (0.12 and $0.24 \mathrm{mM}$ ), the mRNA expression levels of Bax and Bak were increased, the mRNA expression levels of Bcl-2, Bcl-xL and survivin were reduced and the $\mathrm{Bax} / \mathrm{Bcl}-2$ ratio was increased in a dosedependent manner (Fig. 5D). In addition, western blotting revealed a gradual increase in the expression of Bax, caspase
-3 , caspase- 8 and caspase- 9 and a reduction in the expression of Bcl-2 and Bcl-xL in a dose-dependent manner (Fig. 6A). These results indicated that $\beta$-asarone induced the apoptosis of gastric cancer cells by regulating Bax expression and downregulating the expression of $\mathrm{Bcl}-2$ and $\mathrm{Bcl}-\mathrm{xL}$ as well as activating the caspase-cascade response.

Changes in the $M R N A$ and protein expression of invasionrelated genes. In order to investigate the mechanism of $\beta$-asarone in the invasion, migration and adhesion of gastric cancer cells, we assessed changes in the mRNA and protein expression levels of invasion-related genes. The results of both RT-PCR (Fig. 6B) and western blotting (Fig. 6C) revealed that the expression of RECK was significantly increased, while the expression levels of MMP-2, MMP-9 and MMP-14 were decreased in the cells following treatment with $\beta$-asarone as the dose increased. $\beta$-asarone was found to markedly prevent gastric cancer cells from adhering to fibronectin. Therefore, the expression of E-cadherin and $\mathrm{N}$-cadherin which are closely associated with adhesion was further detected. We found that the BGC-823 cells exhibited a dose-dependent increase in E-cadherin and a decrease in $\mathrm{N}$-cadherin following treatment with $\beta$-asarone. 


\section{Discussion}

$\beta$-asarone is one of the main bioactive constituents of the essential oil of Rhizoma Acori Tatarinowii. The inhibitory effect of $\beta$-asarone on gastric cancer cells has been poorly reported, and the detailed underlying anticancer mechanism remains unclear. Here, for the first time, we investigated the potential abilities of $\beta$-asarone to resist gastric cancer growth. The present study found that $\beta$-asarone efficiently suppressed gastric cancer cell viability, induced cell apoptosis and inhibited invasive, migratory and adhesive abilities.

Apoptosis refers to programmed cell death. A dynamic balance between apoptosis and proliferation is crucial to maintaining cell stability and preventing carcinogenesis. At present, the choice of anticancer drugs is often based on biochemical properties of apoptosis. Thus, once inhibition of the gastric cancer cell proliferation by $\beta$-asarone was confirmed, its effect on the apoptosis of gastric cancer cells was examined. The study found obvious morphological apoptotic changes in the gastric cancer cells following treatment with $\beta$-asarone; meanwhile, flow cytometry also revealed that obvious apoptosis occurred in the gastric cancer cell lines $24 \mathrm{~h}$ after $\beta$-asarone treatment.

Caspases play a crucial role in cell apoptosis. They are a type of protease hydrolysates, usually existing in the form of procaspases. According to different initiative factors and pathways, cell apoptosis is divided into two categories: exogenous apoptosis and endogenous apoptosis. In regards to exogenous apoptosis, the interaction between death ligands and receptors causes intracellular structural change to attract pro-caspase- 8 to cut and activate itself. Activated caspase- 8 then activates downstream caspases such as caspase-3, caspase- 6 and caspase-7 which induces cell apoptosis by shearing cytoplasm and nuclear substrates (7). Endogenous apoptosis referring to a condition when the cell is stimulated, promotes the release of apoptotic proteins, such as cytochrome $c$, from the mitochondria to the cytoplasm recruiting pro-caspase-9 to construct protein complexes and apoptotic bodies. Meanwhile, activated caspase- 9 induces activation of caspase-3, caspase- 6 and caspase-7 belonging to downstream caspases and finally intiating the apoptosis process (8-10). Therefore, it is the active caspase family that is the main executor of the apoptotic process. In the present study, western blot results showed that $\beta$-asarone increased the expression of caspase-3, caspase- 8 and caspase- 9 proteins. The inducing effect of $\beta$-asarone on gastric cancer cells was probably due to endogenous and exogenous apoptosis.

In the process of cell apoptosis, Bcl-2 is another crucial gene family. The Bcl-2 family mainly participates in apoptosis regulation through coordination with mitochondria (11). They are divided into two types based on different functions: anti-apoptotic protein, represented by $\mathrm{Bcl}-2$ and $\mathrm{Bcl}-\mathrm{xL}$ and pro-apoptotic proteins, Bax and Bak. Bcl-2 regulates transport across the reticulum and prevents the release of cytochrome $c$, thus the cascade reaction process of apoptosis is inhibited. However, Bax is a pro-apoptotic gene, and the increasing expression of Bax improves antagonistic Bcl-2 and Bcl-xL to promote apoptosis (12). The balance between Bcl-2 and Bax determines the start of cell apoptosis (13). Once the ratio of $\mathrm{Bax} / \mathrm{Bcl}-2$ increases, a series of complicated cascade reac- tions and the signal transmissions in the cell induce the start of apoptosis which leads to cell death $(14,15)$. The present experiment showed that at $24 \mathrm{~h}$ after $\beta$-asarone treatment in the gastric cancer cells, $\mathrm{Bcl}-2$ and $\mathrm{Bcl}-\mathrm{xL}$ were downregulated, while Bax and Bak were upregulated and the Bax/Bcl-2 ratio increased in a concentration-dependent manner. This was possibly an aspect of the molecular mechanisms of apoptosis in gastric cancer cells induced by $\beta$-asarone.

In addition to apoptosis inhibition, local invasion and distant metastasis are the most important biological features of malignant tumors. To elucidate the effect of $\beta$-asarone on the motility of gastric cancer cells, their migration and invasion were detected by wound-healing migration and chamber invasion assays, respectively. $\beta$-asarone was found to have a significant effect on the inhibition of cell migration and invasion.

Epithelial-mesenchymal transition (EMT) plays a pivotal role in tumor metastasis (16). The transition of cells from an epithelial phenotype into a mesenchymal phenotype endows tumor cells with greater invasiveness and motility by resulting in the loss of polarity of the cells, damaging the cell connection and reorganizing the intracellular actin cytoskeleton $(17,18)$.

Typical molecular markers of EMT include a decrease in the expression of epithelial markers such as E-cadherin and an increase in the expression of mesenchymal markers such as $\mathrm{N}$-cadherin (19). In the present study, $\beta$-asarone was found to reverse the process of EMT by lowering $\mathrm{N}$-cadherin and raising E-cadherin levels.

Moreover, the expression and secretion of several ECM-degrading proteolytic proteases such as matrix metalloproteinases (MMPs), play an important role in promoting the process of metastasis (20). Of the MMP family, MMP-2, MMP-9 and MMP-14 are important for degrading the natural barrier basement membrane $(21,22)$. RECK, as a critical MMP suppressor, potently inhibits tumor angiogenesis and metastasis (23). Recent studies have demonstrated that RECK inhibited at least three types of MMPs, including MMP-2, MMP-9 and MMP-14, to prevent tumosr from transmembrane metastasis $(24,25)$. The present study found that the expression of MMP-2, MMP-9 and MMP-14 in the gastric cancer cells was decreased, while RECK was increased in a concentrationdependent manner after treatment with $\beta$-asarone. This may be an important mechanism of the inhibition by $\beta$-asarone of gastric cancer cell invasion and metastasis. However, as a complex molecular process, invasion and metastasis of cancer cells need further study.

Collectively, the present study demonstrated that $\beta$-asarone inhibited the gastric cancer cell growth by upregulating the expression of caspase-3, caspase- 8 and caspase-9, Bax, Bak, RECK, E-caderin and downregulating the expression of Bcl-2, Bcl-xL, MMP-2, MMP-9, MMP-14 and N-caderin. Additionally, $\beta$-asarone inhibited cancer cell growth by inducing apoptosis and prohibiting migration. The anticancer effect of $\beta$-asarone thus warrants further in vivo testing, and its specific effective concentration and its mechanism in detail require further investigation.

\section{Acknowledgements}

This study was supported by the Foundation of the Priority Academic Program Development of Jiangsu Higher Education 
Institutions (PAPD), by the National Natural Science Foundation of China (nos. 81202954 and 81473605).

\section{References}

1. Gomceli I, Demiriz B and Tez M: Gastric carcinogenesis. World J Gastroenterol 18: 5164-5170, 2012.

2. Dong $\mathrm{H}$, Gao Z, Rong $\mathrm{H}$, Jin $\mathrm{M}$ and Zhang $\mathrm{X}$ : $\beta$-asarone reverses chronic unpredictable mild stress-induced depressionlike behavior and promotes hippocampal neurogenesis in rats. Molecules 19: 5634-5649, 2014.

3. Yang YX, Chen YT, Zhou XJ, Hong CL, Li CY and Guo JY: Beta-asarone, a major component of Acorus tatarinowii Schott, attenuates focal cerebral ischemia induced by middle cerebral artery occlusion in rats. BMC Complement Altern Med 13: 236, 2013.

4. Liu XC, Zhou LG, Liu ZL and Du SS: Identification of insecticidal constituents of the essential oil of Acorus calamus rhizomes against Liposcelis bostrychophila Badonnel. Molecules 18: 5684-5696, 2013.

5. Lee SH, Kim KY, Ryu SY, Yoon Y, Hahm DH, Kang SA, Cho SH, Lim JS, Moon EY, Yoon SR, et al: Asarone inhibits adipogenesis and stimulates lipolysis in 3T3-L1 adipocytes. Cell Mol Biol (Noisy-le-grand) 56 (Suppl): OL1215-OL1222, 2010.

6. Zou X, Liu SL, Zhou JY, Wu J, Ling BF and Wang RP: Beta-asarone induces LoVo colon cancer cell apoptosis by up-regulation of caspases through a mitochondrial pathway in vitro and in vivo. Asian Pac J Cancer Prev 13: 5291-5298, 2012.

7. Garg S, Narula J and Chandrashekhar Y: Apoptosis and heart failure: Clinical relevance and therapeutic target. J Mol Cell Cardiol 38: 73-79, 2005.

8. Ghavami S, Hashemi M, Ande SR, Yeganeh B, Xiao W, Eshraghi M, Bus CJ, Kadkhoda K, Wiechec E, Halayko AJ, et al: Apoptosis and cancer: Mutations within caspase genes. J Med Genet 46: 497-510, 2009

9. Majors BS, Betenbaugh MJ and Chiang GG: Links between metabolism and apoptosis in mammalian cells: Applications for anti-apoptosis engineering. Metab Eng 9: 317-326, 2007.

10. Fan TJ, Han LH, Cong RS, Liang J: Caspase family proteases and apoptosis. Acta Biochim Biophys Sin (Shanghai) 7: 719-727, 2005.

11. Autret A and Martin SJ: Emerging role for members of the Bcl-2 family in mitochondrial morphogenesis. Mol Cell 36: 355-363, 2009.

12. Brooks $\mathrm{C}$ and Dong Z: Regulation of mitochondrial morphological dynamics during apoptosis by Bcl-2 family proteins: $\mathrm{A}$ key in Bak? Cell Cycle 6: 3043-3047, 2007.

13. Ghoneum M, Matsuura M, Braga M and Gollapudi S: S. cerevisiae induces apoptosis in human metastatic breast cancer cells by altering intracellular $\mathrm{Ca}^{2+}$ and the ratio of Bax and Bcl-2. Int J Oncol 33: 533-539, 2008.
14. Salakou S, Kardamakis D, Tsamandas AC, Zolota V, Apostolakis E, Tzelepi V, Papathanasopoulos P, Bonikos DS, Papapetropoulos T, Petsas T, et al: Increased Bax/Bcl-2 ratio up-regulates caspase- 3 and increases apoptosis in the thymus of patients with myasthenia gravis. In Vivo 21: 123-132, 2007.

15. Zhang $\mathrm{H}$ and Rosdahl I: Bcl-xL and bcl-2 proteins in melanoma progression and UVB-induced apoptosis. Int J Oncol 28: 661-666, 2006.

16. Acloque H, Thiery JP and Nieto MA: The physiology and pathology of the EMT. Meeting on the epithelial-mesenchymal transition. EMBO Rep 9: 322-326, 2008.

17. Tsai JH and Yang J: Epithelial-mesenchymal plasticity in carcinoma metastasis. Genes Dev 27: 2192-2206, 2013.

18. Wells A, Chao YL, Grahovac J, Wu Q and Lauffenburger DA: Epithelial and mesenchymal phenotypic switchings modulate cell motility in metastasis. Front Biosci 16: 815-837, 2011.

19. Zeisberg M and Neilson EG: Biomarkers for epithelial-mesenchymal transitions. J Clin Invest 119: 1429-1437, 2009.

20. Tsareva SA, Moriggl R, Corvinus FM, Wiederanders B, Schütz A, Kovacic B and Friedrich K: Signal transducer and activator of transcription 3 activation promotes invasive growth of colon carcinomas through matrix metalloproteinase induction. Neoplasia 9: 279-291, 2007.

21. Seiler R, Thalmann GN and Fleischmann A: MMP-2 and MMP-9 in lymph-node-positive bladder cancer. J Clin Pathol 64: 1078-1082, 2011

22. Daniele A, Zito AF, Giannelli G, Divella R, Asselti M, Mazzocca A, Paradiso A and Quaranta M: Expression of metalloproteinases MMP-2 and MMP-9 in sentinel lymph node and serum of patients with metastatic and non-metastatic breast cancer. Anticancer Res 30: 3521-3527, 2010.

23. Clark JC, Thomas DM, Choong PF and Dass CR: RECK - a newly discovered inhibitor of metastasis with prognostic significance in multiple forms of cancer. Cancer Metastasis Rev 26: 675-683, 2007.

24. Omura A, Matsuzaki T, Mio K, Ogura T, Yamamoto M, Fujita A, Okawa K, Kitayama H, Takahashi C, Sato C, et al: RECK forms cowbell-shaped dimers and inhibits matrix metalloproteinasecatalyzed cleavage of fibronectin. J Biol Chem 284: 3461-3469, 2009.

25. Takemoto N, Tada M, Hida Y, Asano T, Cheng S, Kuramae T, Hamada J, Miyamoto M, Kondo S and Moriuchi T: Low expression of reversion-inducing cysteine-rich protein with Kazal motifs (RECK) indicates a shorter survival after resection in patients with adenocarcinoma of the lung. Lung Cancer 58: 376-383, 2007. 